\title{
Melocactus violaceus Pfeiff. (Cactaceae) growth rate and abundance in a sandy terrace of Atlantic Rain Forest (REBIO Guaribas, Paraíba, Brazil)
}

\author{
Niviane Ferreira Lafite ${ }^{1}$ (I) \& Cleber Ibraim Salimon ${ }^{2}$ (i)
}

(1) Universidade Estadual da Paraíba - Campus I, Centro de Ciências Biológicas e da Saúde, Departamento de Biologia, Programa de Pós-graduação em Ecologia e Conservação, Avenida Baraúnas 351, Bairro Universitário 58429-500, Campina Grande, Paraíba, Brazil. E-mail: nivelafite25@gmail.com

(2) Universidade Estadual da Paraíba - Campus V, Centro de Ciências Biológicas Sociais e Aplicadas, Departamento de Biologia, Rua Horácio Trajano de Oliveira, Cristo 58020-540, João Pessoa, Paraíba, Brazil. E-mail: clebsal@gmail.com

Lafite N.F. \& Salimon C.I. (2020) Melocactus violaceus Pfeiff. (Cactaceae) growth rate and abundance in a sandy terrace of Atlantic Rain Forest (REBIO Guaribas, Paraíba, Brazil). Pesquisa e Ensino em Ciências Exatas e da Natureza, 4: e1515. http://dx.doi.org/10.29215/pecen.v4i0.1515

Academic editor: Letícia Carvalho Benitez. Received: 16 October 2019. Accepted: 01 October 2020. Published: 07 October 2020.

Taxa de crescimento e abundância de Melocactus violaceus Pfeiff. (Cactaceae) em um Tabuleiro de Mata Atlântica (REBIO Guaribas, Paraíba, Brasil)

Resumo: Também conhecido como cacto botão, o Melocactus violaceus é uma espécie endêmica do Brasil, que ocorre do Rio Grande do Norte ao Rio de Janeiro. Habita florestas úmidas (Mata Atlântica/restinga), campo rupestre ao Norte (cerrado) crescendo diretamente na areia em meio a arbustos na restinga, dunas ribeirinhas e tabuleiros da Mata Atlântica. Apesar de ter ampla distribuição e ocorrer em áreas protegidas, esta espécie é considerada pela International Union for Conservation of Nature (IUCN) como vulnerável. O objetivo do presente trabalho é estudar a abundância, distribuição de tamanho, e taxa de crescimento em uma população de Melocactus violaceus, que ocorre em tabuleiro numa área de Floresta Estacional Semidecidual, na Reserva Biológica (REBIO) Guaribas, Paraíba. Foram amostradas três fitofisionomias diferentes do tabuleiro, onde uma área é predominantemente fechada, a segunda é aberta, na sua grande parte, e por último em uma área onde predomina Lagenocarpus spp., conhecido popularmente como capim azul. Em cada fisionomia marcou-se 10 parcelas de $12.6 \mathrm{~m}^{2}$, com $20 \mathrm{~m}$ de distância entre cada uma, onde indivíduos foram marcados e mensurados. A espécie foi encontrada somente na área aberta, com densidade média de 1.46 ind. $\mathrm{m}^{-1}$ com média de crescimento (em diâmetro) anual dos indivíduos que sobreviveram ao longo de todo estudo foi de $1.76 \pm 1.12 \mathrm{~cm}$ ao ano, com crescimento mínimo de $0.04 \mathrm{~cm}$ e crescimento máximo de $4.7 \mathrm{~cm}$.

Palavras chave: Cacto botão, estrutura populacional, taxa de crescimento de cactus.

Abstract: Also known as Turk's cap cactus or melon thistle, Melocactus violaceus is a Brazilian endemic species, occurring from Rio Grande do Norte to Rio de Janeiro states. It inhabits humid forests (Atlantic Rain Forest and associated shoreline sandy vegetation), rocky soils in savannah vegetation (Cerrado) and in sandy terraces. Despite its wide distribution and occurrence in protected areas, it is considered a vulnerable species in International Union for Conservation of Nature (IUCN) Red List. In this paper, we study abundance, size distribution and growth rate in a population of Melocactus violaceus in the Guaribas Biological Reserve (REBIO), Paraíba, Brazil. We sampled three vegetation types in a sandy terrace, one with a dense covered area with small trees and shrubs, another area with a very open canopy, where sunlight reaches most of the exposed soil, and a third area densely covered by a grassy vegetation dominated by Lagenocarpus spp., locally known as blue grass. In each of these three vegetation types, we made 10 samples of $12.6 \mathrm{~m}^{2}, 20 \mathrm{~m}$ apart from each other, where individuals were measured and tagged. Individuals from this species were found only in the open area, with an average abundance of 1.46 ind. $^{-1}$. Average 
annual growth rate was $1.76 \pm 1.12 \mathrm{~cm} \mathrm{a}^{-1}$, with a minimum growth of $0.04 \mathrm{~cm} \mathrm{a}^{-1}$ and maximum of de 4.7 $\mathrm{cm} \mathrm{a}^{-1}$.

Key words: Cactus button, population structure, cactus growth rate.

\section{Introduction}

Cactaceae is one of the largest eudicot families, with over 90 genera and around 1500 species (Almeida 2016). Thirty seven (37) genera of the family are native to Brazil, which is about $30 \%$ of the total richness known (Zappi et al. 2011). Some of the species that constitute the family are characterized by their ability to inhabit areas with low water availability and high solar incidence; their distribution defined by a specific set of conditions, occurring from North to South America (Almeida 2016). In Brazil, it occurs in areas such as river sand banks, riparian forests, the Caatinga, restinga and low plateau formations within the Atlantic Forest, and Cerrado (Gomes et al. 2014).

Cactaceae are key to the functioning of their ecosystems as a source of energy for a diversity of pollinators and dispersers (Zappi et al. 2011). As an example, Melocactus zehntneri Britton \& Rose, presents an important role in the ecological succession in the environments they occur, being capable of turning inhospitable environments, such as rock outcrops, in habitable areas for other species (Fabricante et al. 2010).

Melocactus is a genus formed by small, globe-shaped cacti, common in the semi-arid regions, with small flowers that blossom in the afternoon and close at dusk. The fruits are small $(\sim 3 \mathrm{~cm})$ and develop protected inside the cephalium, becoming succulent and varying from white to red when ripe, and carrying small black seeds within the pulp (Zappi et al. 2011). Among the species found in Brazil, several are native, such as Melocactus azureus Buining \& Brederoo, Melocactus bahiensis Britton \& Rose, Melocactus conoideus Buining \& Brederoo, Melocactus ernestii Vaupel, Melocactus glaucescens Buining \& Brederoo e Melocactus violaceus Pfeiff. (Zappi et al. 2011).

Melocactus violaceus Pfeiff. is a small, globe-shaped plant, presenting in its upper part a soft white cephalium, which presents short reddish hairs during the reproductive phase, reaching up to $7 \mathrm{~cm}$ in height and $10 \mathrm{~cm}$ in diameter (Figueira et al. 1994). Its fruit are rosecolored, completely exposed when ripe, allowing for the dispersal by lizards and ants (Colaço et al. 2006) which, according to Xavier (2015), Tropidurus hygomi Reinhardt \& Luetken, is one of the responsible for the dispersion of Melocactus violaceus Pfeiff. seeds, where the high nectar concentration would explain the lizard's attraction for the flowers, which themselves have a high carbohydrate budget, being a source of food throughout the year (Gomes et al. 2014). Despite the mutualistic relationship found between Melocactus and its pollinizer and seed disperser, Tropidurus (Gomes et al. 2014), it is possible to obtain excellent germination rates even with seeds that had not passed through the lizard's digestive tract (Zamith et al. 2013).

Also known as "button cactus", Melocactus violaceus Pfeiff. is a species endemic to Brazil, occurring from Northeast to Southeast in altitudes ranging from 0 to $1100 \mathrm{~m}$ (Taylor 1991; IUCN 2013). It inhabits ombrophilous forests (Atlantic Forest/restinga), rock fields in the North (cerrado) growing among bushy vegetation in the sand of coastal restinga, riverside dunes, and low plateau formations in Atlantic Forest (CNC Flora 2012).

The coastal Low plateau formation is a landscape structure constituted of small plateaus, ranging from flat to rugged, limited by barriers with altitude between 20 and 50 meters, that extend from Ceará to Bahia, Espírito Santo and Rio de Janeiro (Embrapa 2014), being characterized in the National Action Plan for the Conservation of the Cactaceae as cerrado scrubland, being then defined as savanna areas with low arboreal density, and abundant underbrush (Zappi et al. 2011).

According to the National Action Plan for the Cactaceae (Zappi et al. 2011), habitat fragmentation, the degradation of environmental quality, mining activities, and the commerce and illegal harvest contribute heavily to the population collapse of species like Melocactus 
violaceus Pfeiff. Other important driver of population decrease in is its economic importance, its use for cattle and human nutrition, in the fabrication of sweets, and its use on traditional medicine where Melocactus is used in the confection of molasses used to treat the flu, bronchitis and cough (Taylor 1991; Zappi et al. 2011).

Despite its wide distribution and occurrence within protected areas, this species is considered by the IUCN (2013) as vulnerable due to habitat destruction for urbanization, tourism, road construction, artificial landscaping and agribusiness. Consequently, some populations have already disappeared due to agricultural expansion and de environmental degradation of restinga environments for sand mining. Thus, a population decline of at least $30 \%$ is estimated for M. violaceus Pfeiff. due to past and present loss of habitat (IUCN 2013).

Due to its vulnerability and the scarce information about the species' ecology, the present study aims to expand our understanding of the species, specifically on its abundance, size distribution, growth rate and to verify if there is a relationship between size and growth of the species in the Guaribas Biological Reserve (REBIO), a federal conservation unit located in the state of Paraíba/BR. From the conservation point of view, including population recovery in cases of local extinction, it is important to estimate the turnover time of a viable population in the region.

\section{Material and Methods}

\section{Study area}

According to the Operation Plan for the Combat of Forest Fires (Brasil 2006), the Guaribas Biological Reserve was created in 1990 with the main goal of maintaining Atlantic Forest remnants in Paraíba, and thereby protecting endemic and threatened species.

This study was developed in an area of coastal low plateau within the REBIO Guaribas, located in the municipality of Mamanguape - PB, starting in 2014 and ending in 2017. With intense anthropogenic influence, the area is located in the margin of the BR 101 highway, which facilitates the entrance of people, as there are no fences or barriers in place. Another important factor to the large flux of people in the area is the harvest of the Mangaba fruit, Hancornia speciosa Gomes (Apocynaceae), very abundant and is a source of income to several families in the region.

\section{Sampling design}

Thirty (30) plots were delimited in three phyto physiognomies found in the low plateau: one with predominance of small-sized trees and bushes (in the higher part of the terrain); the second is dominated by herbaceous vegetation with small, spaced islands of trees and bushes (an intermediary position on the terrain's relief); and lastly na area where there is a dense and almost exclusive of Lagenocarpus spp. (Cyperaceae) (the lowest part of the terrain, prone to flooding during the rain period) popularly known as "blue grass" (Figure 1).

In each physiognomy, 10 circular plots of $12.6 \mathrm{~m}^{2}$ were installed, $20 \mathrm{~m}$ from each other on a transect. The demarcation of the plots was done randomly in a straight line parting from the first plot, with northbound direction. To obtain the abundance data, we accounted for all individuals within $1 \mathrm{~m}$ of each side of the central line along the 200 meter long transect. For the description of the size distribution for the population, the same individuals were measured. For each individual, we registered whether it was in the reproductive stage (with the presence of the cephalium, flower or fruit). In total, 52 individuals were initially marked, numbered and tagged, with their diameter measured with the aid of a caliper, to estimate individual growth rate. These measurements occurred on 07/23/2014, 03/04/2016, 07/15/2016, 10/14/2016 and 03/01/2017, with five measurements in total throughout the study. The individuals were differentiated as reproductive when presenting flowers and/or fruit, and immature without flowers or fruit.

The data was organized in a spreadsheet, where the growth rate was calculated following the formula (Silk 1984): 


\section{Melocactus violaceus in Northeastern Atlantic Rain Forest}

$$
T_{c}=\frac{\Delta D}{\Delta t}
$$

Where: $T_{c}$ is the growth rate; $\Delta D$ is the variation in diameter and $\Delta t$ is the interval of time between measurements.

Abundance was estimated by the mean number of individuals per square meter. Size classes for both diameter and height were created, with the classes plotted in a histogram and a graph relating the height and diameter of the individuals.

We performed a correlation analysis between the initial diameter and the total growth (initial diameter - final diameter / time interval) of all individuals alive throughout the duration of the study. And from this relationship, we performed a regression and correlation between the two variables to verify if there is a significant correlation between them, as to test if the size interferes positively in the growth rate.

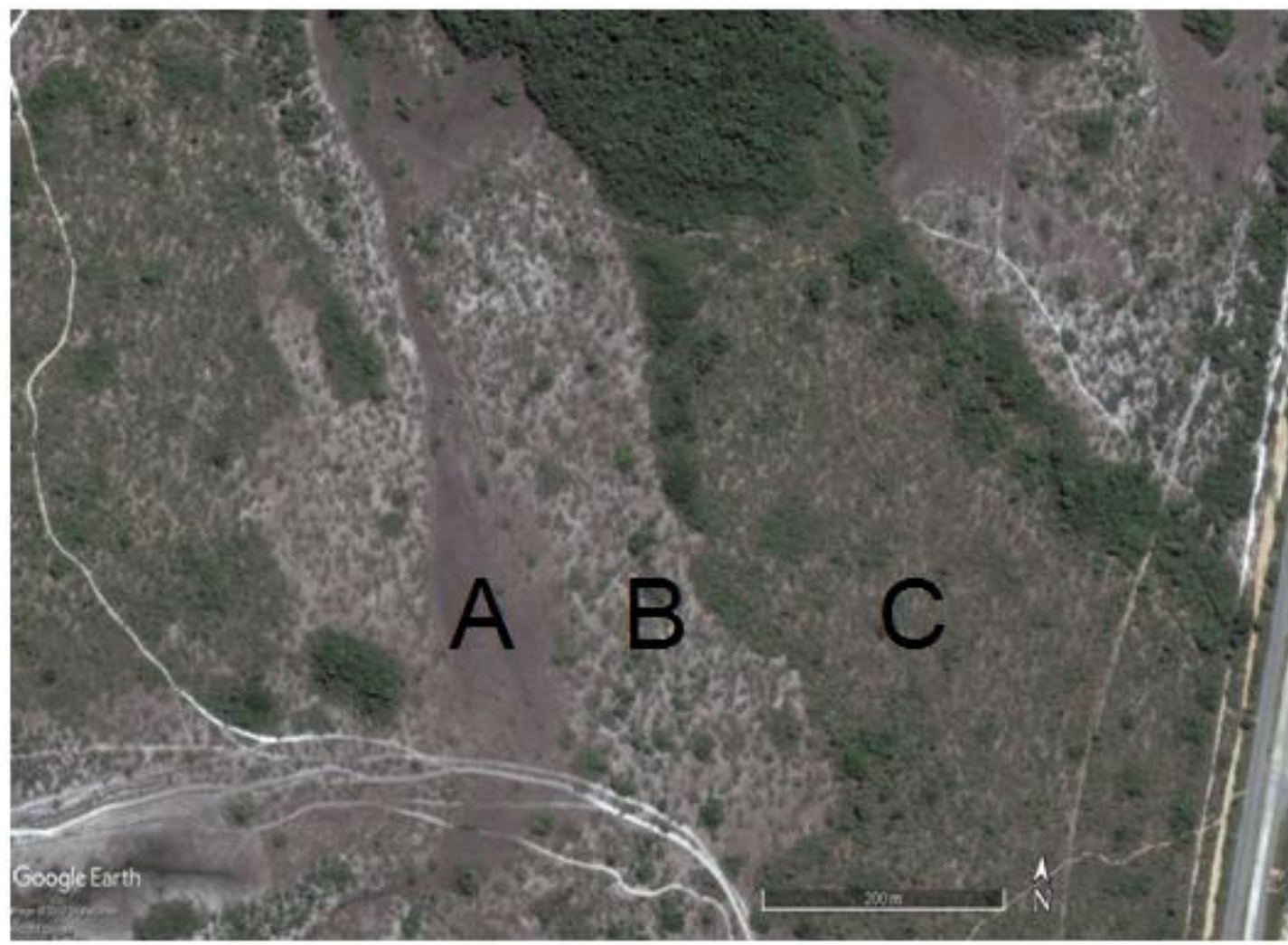

Figure 1. REBIO Guaribas, between 2014 and 2017: A. Area with predominance of blue grass, lowest part of the terrain; B. Area dominated by herbaceous vegetation, intermediary part of the terrain; G. Area with predominance of small-sized trees and shrubs, highest point in the terrain.

\section{Results}

Regarding the spatial distribution, in areas with a more dense vegetation and areas with dominance of Lagenocarpus spp., no individuals of $M$. violaceus Pfeiff. were found. However, in the more open area, we observed individuals, tallying up to 52 individuals marked for the growth rate monitoring. During the study, 15 individuals died or had their plates removed, leaving a total of 37 with data usable for the sampled period.

The mean abundance (from the 292 individuals distributed in $200 \mathrm{~m}^{2}$ ) was 1.46 ind. $\mathrm{m}^{-1}$. The abundance of dead individuals was of 0.14 ind. $\mathrm{m}^{-1}$ and of fertile individuals 0.04 ind. $\mathrm{m}^{-1}$. Three percent (3\%) of the individuals (9 individuals) were in reproductive stage, showed average height of $5.82 \pm 1.26 \mathrm{~cm}$, with a maximum height of $7.96 \mathrm{~cm}$ and minimum of $3.87 \mathrm{~cm}$, and mean diameter of $13.47 \pm 0.65 \mathrm{~cm}$, with a maximum diameter of $14.26 \mathrm{~cm}$ and minimum of 12.4 $\mathrm{cm}$. 
Immature individuals showed a mean height of $1.83 \pm 1.23 \mathrm{~cm}$, with a maximum height of $6.99 \mathrm{~cm}$ and minimum of $0.15 \mathrm{~cm}$; mean diameter of $5.40 \pm 2.89 \mathrm{~cm}$, with minimum diameter of $0.99 \mathrm{~cm}$ and maximum of $13.63 \mathrm{~cm}$. When examining the relationship between height and diameter, we noticed that there is a strong coefficient of determination $\left(\mathrm{r}^{2}=0.81\right)$ between the variables, indicating that the taller individuals also had the largest diameters (Figure 2).

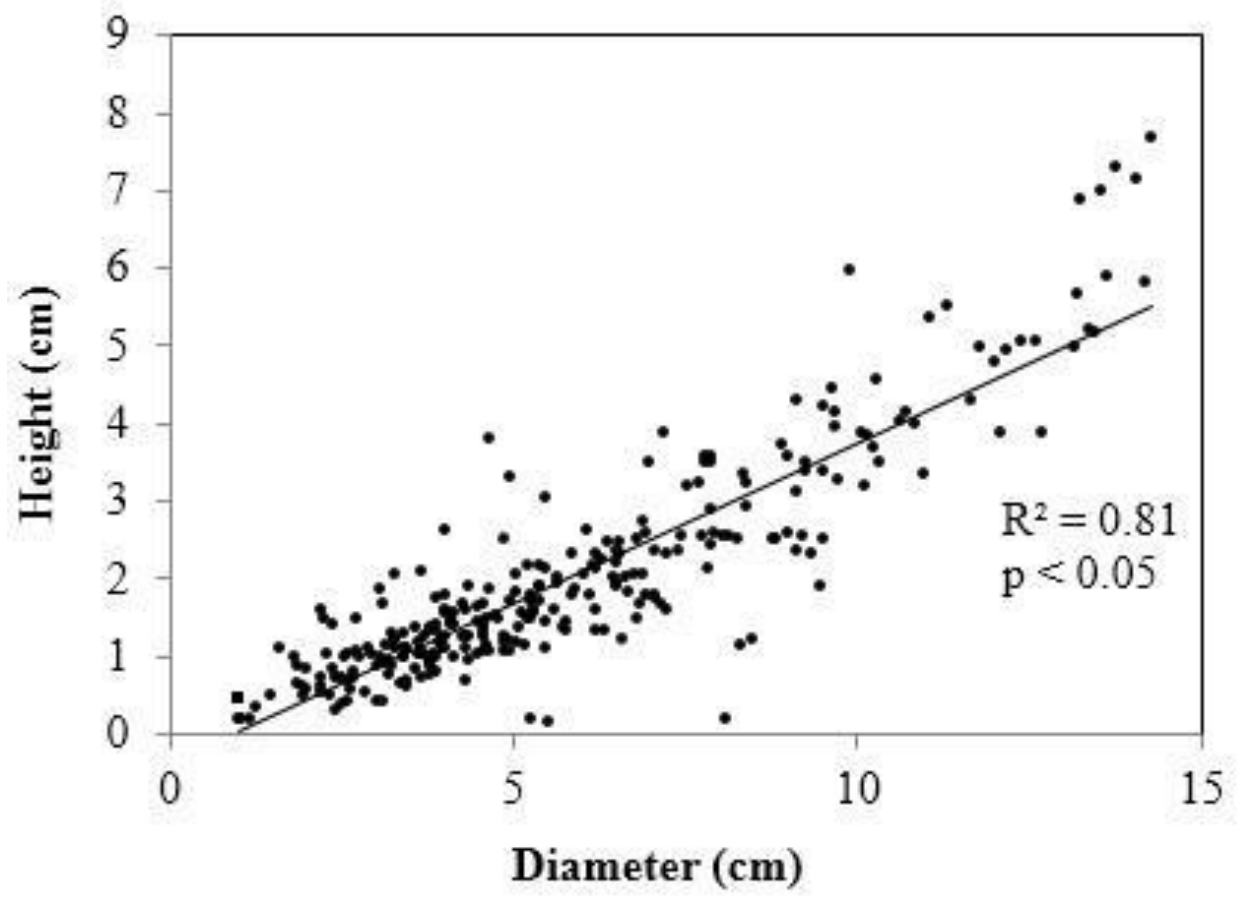

Figure 2. Strong relationship between height and diameter for the 292 individuals of Melocactus violaceus Pfeiff. measured in REBIO Guaribas between 2014 and 2017.

Of the 292 individuals registered within the transect, $9.6 \%$ showed diameters between 0.1 $\mathrm{cm}$ and $1.99 \mathrm{~cm} ; 51.7 \%$ of the population presented diameter between $2 \mathrm{~cm}$ and $5.99 \mathrm{~cm}$; with $27.7 \%$ presenting diameter between $6 \mathrm{~cm}$ and $9.99 \mathrm{~cm}, 10.9 \%$ presented diameter larger than 10 $\mathrm{cm}$ and $9.93 \%$ were dead (Figure 3). Regarding height, over $70 \%$ of individuals were between 2 $\mathrm{cm}$ and $4 \mathrm{~cm}$ tall.

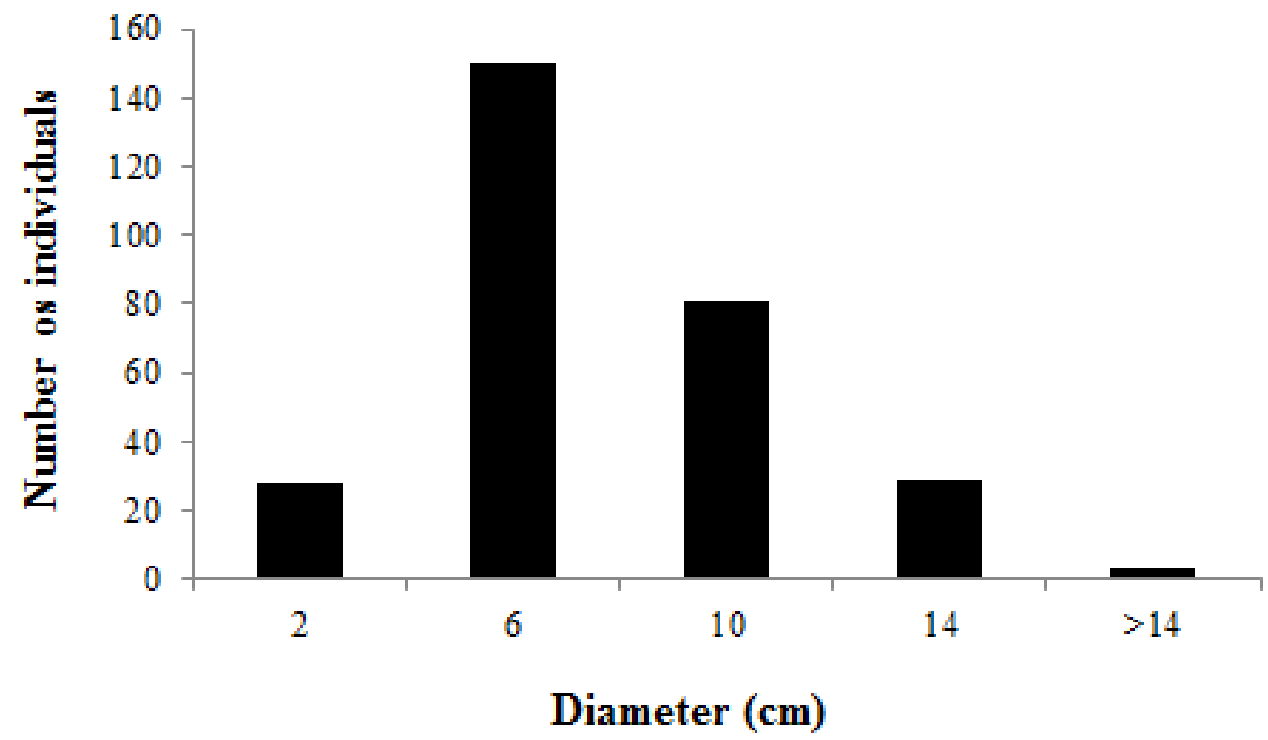

Figure 3. Diameter histogram of individuals of Melocactus violaceus Pfeiff. per size $(\mathrm{cm})$. REBIO Guaribas$\mathrm{PB} / \mathrm{BR}$. 
Mean annual growth of the tagged individuals (37) which survived the entire study period was $1.76 \pm 1.12 \mathrm{~cm} \mathrm{a}^{-1}$, with minimum of 0.04 and maximum of $4.7 \mathrm{~cm} \mathrm{a}^{-1}$. The regression testing whether larger individuals had higher growth rates, we observed that there was no relation $\left(R^{2}=0.043, p>0.05\right)$. Hence, size does not interfere in the growth rate (Figure 4).

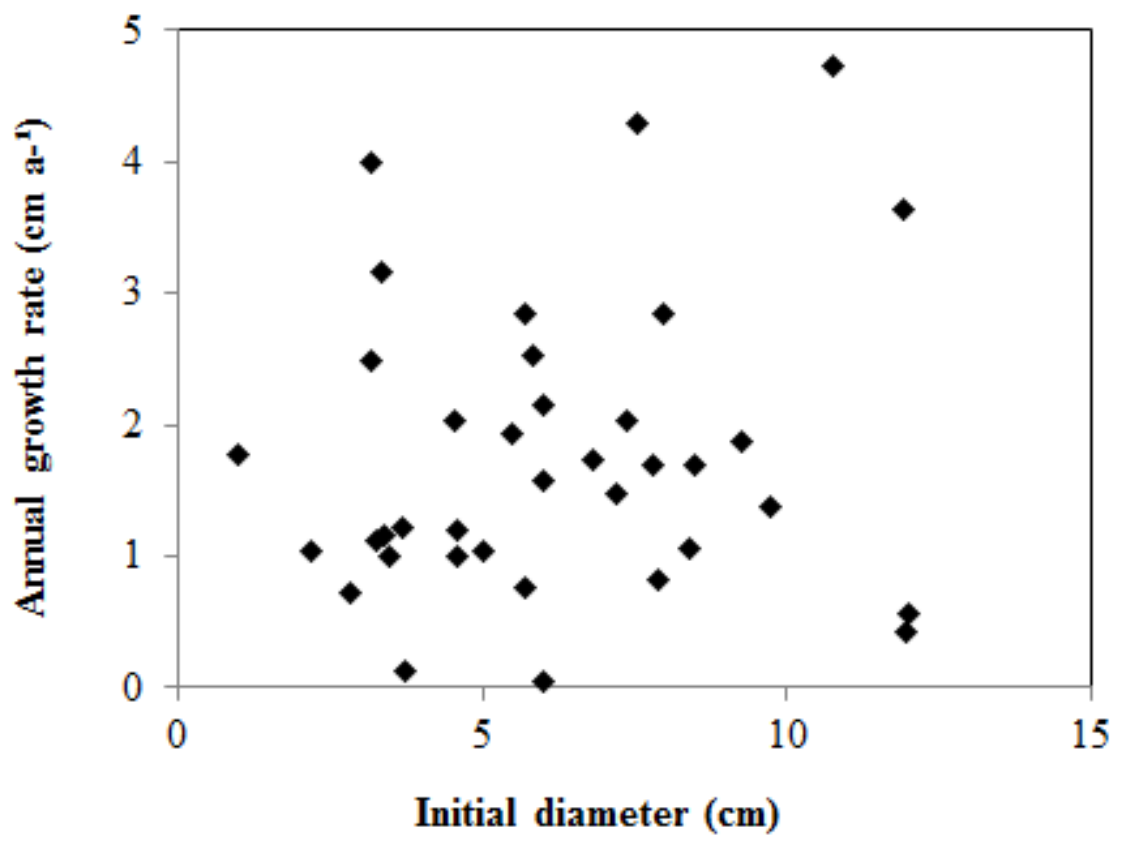

Figure 4. Insignificant relationship between diameter and annual growth rate of 37 individuals of $\boldsymbol{M}$. violaceus Pfeiff. REBIO Guaribas between 2014 and 2017.

\section{Discussion}

Differing from the findings of Figueiredo (2016), where over half of the population was in pre-reproductive and reproductive stages, totalizing $56.5 \%$ of the population, only $3 \%$ of the individuals registered in our study were in reproductive stage, being closer to the population structure observed by García-González et al. (2016), where $28.7 \%$ of the Melocactus nagyi Z. Mészáros population was reproductive.

Based on the 292 individuals in the transect, the largest portion of dead individuals was concentrated between 6 to $9.9 \mathrm{~cm}$ in diameter (Figure 5). Hughes et al. (2011) when studying Melocactus ernestii Vaupel, observed that $76 \%$ of the individuals found dead were in the juvenile stage, with $<3 \mathrm{~cm}$ in diameter, which, according to the author, was due to environmental oscillations. However, in a study conducted by Freire (2013), no significant difference was found in the survival rate for the different size classes.

We observed that in the areas dominated by Lagenocarpus spp. (blue grass), M. violaceus Pfeiff. did not occur. It is possible that there is some type of competition between species, as one predominates over the other, with the added possibility of exclusion of Melocactus violaceus Pfeiff. due to seasonal flooding during the rainy season as it is the lowest part of the terrain, making it difficult for $M$. violaceus Pfeiff. individuals to survive in the area. However, in the more open area, there was a noticeable abundance of $M$. violaceus Pfeiff., although under some of the larger cashew trees (Anacardium occidentale L.) found in two plots, there were no specimens found, probably due to the low luminosity that would consequently hinder photosynthesis, as the soil was always covered by a litter of leaves.

The closer the plots were from the trees that shaded the soil completely, the number of individuals diminished, reaching zero in some of the plots; and the proximity to such tree individuals can influence the population density (Brito et al. 2007) as in some plots, the soil was completely shaded, as well as covered by a large quantity of litter that could hinder the growth 
of seedlings by insufficient sunlight, as could be observed for Melocactus bahiensis Britton \& Rose, where the ideal level of shade for its development is $20 \%$ (Lone et al. 2009).

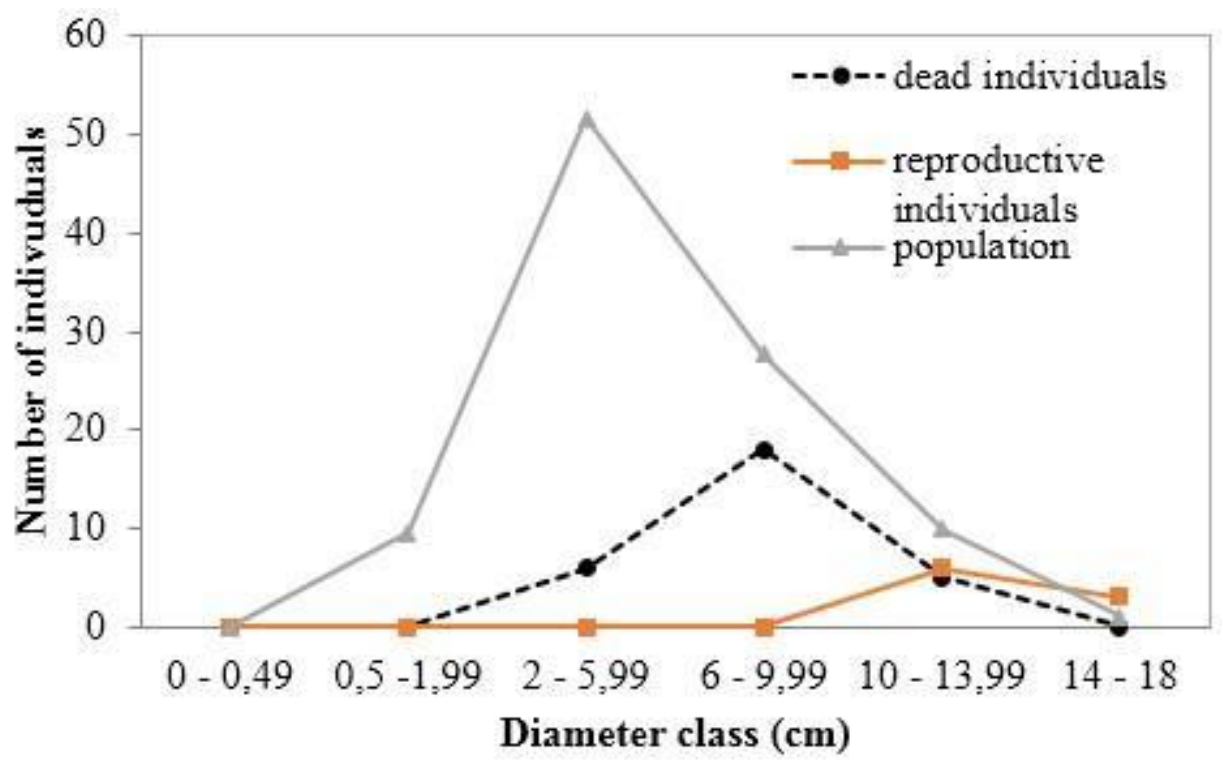

Figure 5. Relationship between percentage of dead and reproductive individuals in the population by size class of Melocactus violaceus Pfeiff. a the REBIO Guaribas-PB/BR.

Size class distribution of individuals presented a similar frequency as reported by Figueiredo (2016), where most of the population studied in the Jurubatiba National Park in Rio de Janeiro had mean diameter between 4 to $7 \mathrm{~cm}$. The same population structure occurs with Melocactus nagyi Z. Mészáros (Melocactus harlowii Britton \& Rose Vaupel)(García- González et al. 2016).

Immature individuals corresponded to the larger portion of the population, where only a small percentage was in the reproductive stage, a trend also observed in other species of Melocactus. Fabricante et al. (2010) studying Melocactus zehntneri Britton \& Rose at an inselberg in the Caatinga of Paraíba, observed that the major part of the population was of immature individuals which, according to the author, could be caused by the competition as a consequence of the low resource availability that impedes many individuals of completing their life cycle.

From the tagged individuals for the growth rate study, only one individual in the seedling phase died, differing from the findings of Hughes et al. (2011) in a fragment of Deciduous Forest in Bahia, where $75.9 \%$ of the seedlings of Melocactus ernestii Vaupere died, and individuals bigger than $3 \mathrm{~cm}$ had higher survival rates.

Mean abundance found in our study was similar to the findings of Brito et al. (2007), in their study of the population structure of $M$. Conoideus Buining \& Brederoo at the Serra do Periperi Municipal Park (BA), where a density of 1.2 individuals per $\mathrm{m}^{2}$ was reported.

Regarding diameter and height, these parameters can vary according to each species in the genus. For example, Melocactus schatzlii H. Till \& R. Gruber reaches up to $22-25 \mathrm{~cm}$ height, while Melocactus andinus R. Gruber \& N.P. Taylor reaches $40 \mathrm{~cm}$ (Nassar et al. 2007). Melocactus curvispinus Pfeiff. subs. Cucutensis presents height and diameter around 11-13 cm, while $M$. curvispinus Pfeiff. subs. lobelli, can reach $20-25 \mathrm{~cm}$ in height (Fernández-Alonso \& Xhonneux 2002). In a study by Fabricante et al. (2013) with Melocactus ernestii Vaupel subsp. Ernestii the mean diameter was $16.5 \mathrm{~cm}$, while mean height was $13.6 \mathrm{~cm}$, our data for $M$. violaceus Pfeiff. did not surpass $7.96 \mathrm{~cm}$ of height. Such differences may be due to soil characteristics and survival strategies in terms of where to allocate water storing tissues.

Considering the mean annual growth of $1.76 \pm 1.12$ and the minimal diameter recorded in the reproductive phase of $12 \mathrm{~cm}$, we estimate that it takes roughly 6.8 years for an individual of Melocactus violaceus Pfeiff. to reach the adult phase, assuming linear growth rates 
throughout the lifespan of an individual, which is reasonable, since we found no correlation between diameter and growth rate.

\section{Conclusion}

Based on the data presented in this paper, with an average abundance of 1.46 ind. $\mathrm{m}^{-2}$, $3 \%$ of the population in reproductive state and an average annual growth rate of $1.76 \pm 1.12 \mathrm{~cm}$, we believe that this local population is viable and is not in danger of local extinction. Nevertheless, local fires might be a cause for concern, since we have not up to date any data on the death rate after fires in the area, which happen sometimes.

\section{Acknowledgements}

The authors would like to thank the staff at the REBIO Guaribas and Dr. Sérgio Romero da Silva Xavier (UEPB) for identifying the species and reviewers of this work.

\section{References}

Almeida S. (2016) Enciclopédia Temática. Cactaceae, Família (Cactos). Available: http://knoow.net/ciencterravida/botanica/cactaceae-familia-catos/ (Accessed: March 2017).

Brito K.S., Oliveira H.M.F., Melo J.R.F., Morais C.G., Sá-Neto R.J. \& Corrêa M.M. (2007) Efeito da Densidade da Cobertura Vegetal na População de Melocactus Conoideus (Cactaceae) no Parque Municipal Serra Do Periperi. In: Anais do VIII Congresso de Ecologia do Brasil. Caxambu, Minas Gerais.

Brasil (2006) Instituto Brasileiro do Meio Ambiente e Recursos Naturais Renováveis - IBAMA. Plano Operativo de Prevenção e Combate aos Incêndios Florestais na Reserva Biológica Guaribas. Mamanguape, Paraíba.

CNC Flora (2012) Melocactus violaceus subsp. ritteri in Lista Vermelha da flora brasileira versão 2012.2 Centro Nacional de Conservação da Flora. Available: http://cncflora.jbrj.gov.br/portal/pt-br/profile/Melocactus violaceus subsp. ritteri./ (Accessed: March 2017).

Colaço M.A.S., Fonseca R.B.S., Lambert S.M., Machado C.G. \& Borba E.L. (2006) Biologia reprodutiva de Melocactus glaucescens Buining \& Brederoo e $M$. paucispinus G. Heimen \& R. Paul (Cactaceae), na Chapada Diamantina, Nordeste do Brasil. Revista Brasileira de Botânica, 29(2): 239-249. https://doi.org/10.1590/S0100-84042006000200005

Embrapa (2014). Embrapa Tabuleiros Costeiros. Delimitação da área de atuação da Embrapa Tabuleiros Costeiros. Relatório Final. Aracaju, Sergipe.

Fabricante J.R. \& Oliveira C.R.S. (2013) Estrutura populacional de Melocactus ernestii Vaupel subsp. ernestii (Cactaceae). Scientia Plena, 9: 1-8.

Fabricante J.R., Andrade L.A. \& Marques F.J. (2010) Caracterização populacional de Melocactus zehntneri(Britton \& Rose) Luetzelburg (Cactaceae) ocorrente em um inselbergue da Caatinga paraibana. Biotemas, 23(1): 61-67. https://doi.org/10.5007/2175-7925.2010v23n1p61

Fernández-Alonso J.L. \& Xhonneux G. (2002) Novedades taxonómicas y sinopsis del género Melocatus Link e Otto (Cactaceae) en Colombia. Revista de la Academia Colombiana de Ciencias Exactas, Físicas y Naturales, 26: 353-365.

Figueira J.E.C., Vasconcellos-Neto J., Garcia M.A. \& de Souza A.L.T. (1994) Saurocory in Melocactus violaceus (Cactaceae). Biotropica, 26(3): 295-301. https://doi.org/10.2307/2388850

Figueiredo M.S.L. (2016) Population Biology of the Melon Cactus Melocactus violaceus subsp. violaceus (Cacteceae) on a Brazilian Sandy Coastal Plain. Oecologia Australis, 20(1): 51-57. https://doi.org/10.4257/oeco.2016.2001.04

Freire H.P.L. (2013) Efeito do agrupamento espacial na taxa de crescimento e sobrevivência de Melocactus conoideus Buining \& Brederoo (Cactaceae): uma espécie endêmica e ameaçada de extinção do Nordeste do Brasil. Dissertação (Programa de Pós-Graduação em Ciências Ambientais). Universidade Estadual do Sudoeste da Bahia, Itapetinga, Bahia. 
García-González A., Riverón-Giró F.B., González-Ramírez I.S., Domenech R.Y.E., Montero Y.H. \& Verdecia E.P. (2016) Características poblacionales y ecología del endemismo cubano Melocactus nagyi (Cactaceae), en la Reserva Florística Manejada El Macío, Cuba. Revista Cubana de Ciencias Biológicas, 5: 33-42.

Gomes V.G.N., Quirino Z.G.M. \& Machado I.C. (2014) Pollination and seed dispersal of Melocactus ernestii Vaupel subsp. ernestii (Cactaceae) by lizards: an example of double mutualism. Plant Biology, 16(2): 315-322. https://doi.org/10.1111/plb.12063

Hughes F.M., De La Cruz M., Romão R.L. \& De Castro M.S. (2011) Dinâmica espaço-temporal de Melocactus ernestii subsp. Ernestii (Cactaceae) no Nordeste do Brasil. Revista Brasileira de Botânica, 34(3): 389-402. https://doi.org/10.1590/S0100-84042011000300012

IUCN (2013) The IUCN Red List of Threatened Species. Version 2016-3. Available: www.iucnredlist.org (Acessed 16 April 2017).

Lone A.B., Takahashi L.S.A., Faria R.T. \& Destro D. (2009) Desenvolvimento vegetativo de Melocactus bahiensis (Cactaceae) sob diferentes níveis de sombreamento. Revista Ceres, 56(2): 199-203.

Nassar J.M., Ramirez N., Lampo M., Gonzalez J.A., Casado R. \& Nava F. (2007) Reproductive biology and mating system estimates of two Andean Melocacti, Melocactus schatzlii and $M$. andinus (Cactaceae). Annals of Botany, 99(1): 29-38. https://doi.org/10.1093/aob/mcl229

Silk W.K. (1984) Quantitative descriptions of development. Annual Review of Plant Physiology, 35(1): 479-518. https://doi.org/10.1146/annurev.pp.35.060184.002403

Taylor N.P. (1991) The genus Melocactus (Cactaceae) in Central and South America. Bradleya, 9: 1-80. https://doi.org/10.25223/brad.n9.1991.a1

Xavier M.A. \& Dias E.J.R. (2015) First record of the Brazilian restinga lizard Tropidurus hygomi ingesting a fruit of Melocactus violaceus (Cactaceae). Herpetology Notes, 8: 437-438.

Zamith L.R., Cruz D.D. \& Richers B.T.T. (2013) The effect of temperature on the germination of Melocactus violaceus Pfeiff. (Cactaceae), a threatened species in restinga sandy coastal plain of Brazil. Anais da Acadêmia Brasileira de Ciências, 85(2): 615-622. https://doi.org/10.1590/S0001-37652013000200010

Zappi D., Taylor N., Silva S.R., Machado M., Moraes E.M., Calvente A., Cruz B., Correia D., Larocca J., Assis J.G.A., Aona L., Menezes M.O.T., Meiado M., Marchi M.N., Santos M.R., Bellintani M., Coelho P., Nahoum P.I. \& Resend S. (2011) Plano de ação nacional para a conservação das Cactáceas. Instituto Chico Mendes de Conservação da Biodiversidade. Brasília: ICMBio. Available: http://www.icmbio.gov.br/portal/images/stories/docs-plano-deacao/pan_cactaceas/livro_cactaceas_web.pdf. (Accessed: April 2019). 